\title{
FUNGSI MASJID TERHADAP PENGELOLAAN PENGEMBANGAN MASYARAKAT ISLAM (PENGEMBANGAN KEUMATAAN)
}

\author{
Rahmat Hidayat \\ Institut Agama Islam An Nur Lampung \\ Jalan Pesantren No. 01, Sidoharjo, Jati Agung, 35365 Lampung Selatan Lampung \\ Hidayatrahmat677@gmail.com
}

\begin{abstract}
The mosque has a very large role and function in all dimensions of Muslim life. Where the mosque is a symbol that illustrates the strength map of the people and can unite and realize every meaning of goodness. Without mosque, the unity of the Muslims will be easily broken even divorced. The mosque is not just a place of worship, but all aspects of life problems of the people and the development and fostering of the community (people) of Islam can be resolved from the mosque. However, Along with the times, the mosque experienced a shift in values, where the mosque is no longer functioned as a function that has been exemplified by the Prophet Muhammad Saw. Based on this concern, some Muslims are aware and care about the condition of the mosque that began to be abandoned by the people, and it can be realized that lately there have been emerging movements that have encouraged the functioning of the mosque as it was in the early days of Islam. As an effort in managing the mosque by implementing several functions such as: planning, organizing, leadership actualization, supervision and evaluation become a structured management process. And this matter is combined with the development of human rights or the development of Islamic society. Awareness of the people of worship hereafter and balancing faith in worldly worship (capacital social).
\end{abstract}

Keywords: Mosque Function, Community Development and Public Relations

\begin{abstract}
Abstrak
Masjid memiliki peran dan fungsi yang sangat besar dalam seluruh dimensi kehidupan umat Islam. Dimana masjid merupakan simbol yang menggambarkan peta kekuatan umat dan dapat menyatukan serta mewujudkan setiap makna kebaikan. Tanpa masjid, persatuan kaum muslimin akan mudah dipatahkan bahkan bercerai-beraikan. Masjid bukan hanya sebagai tempat ibadah semata, namun semua aspek kehidupan masalah umat dan pengembangan serta pembinaan masyarakat (umat) islam dapat diselesaikan di masjid. Namun, Seiring dengan perkembangan zaman, masjid mengalami pergeseran nilai, dimana masjid tidak lagi difungsikan sebagaimana fungsi yang telah dicontohkan oleh Rasulullah Saw. Berdasarkan kepedulian sebagian umat Islam yang sadar dan peduli akan kondisi masjid yang mulai ditinggalkan umat, akhir-akhir ini bermunculan gerakangerakan yang mengajak memfungsikan Masjid sebagaimana masa awal Islam. Sebagai sebuah upaya di dalam mengelola Masjid dengan menerapkan beberapa fungsinya seperti perencanaan (plaining), pengorganisasian (organeizing), aktualisasi kepemimpinan (actuating), pengawasan dan evaluasi (evaluazing) menjadi sebuah proses pengeloloaan yang terstruktur. Dan prihal inilah yang dikomben dengan pengembangan keumatan atau pengembangan masyarakat islam. Kesadaran ummat akan ibadah ahirat dan menyeimbangkan keimanan akan ibadah duniawi (capacital social).
\end{abstract}

Keywords: Fungsi Masjid, Pengembangan Masyarakat dan Keumatan 


\section{Pendahuluan}

Masjid adalah rumah Allah (baitullah) yang dibangun sebagai sarana bagi umat Islam untuk mengingat, mensyukuri, dan menyembah Allah Swt dengan baik ${ }^{1}$. Masjid sejak zaman Rasulullah SAW telah menjadi pusat kegiatan kaum muslimin. Walaupun dari arti katanya masjid merupakan tempat sujud kepada Allah SWT namun sejarah menunjukan bahwa masjid tidak semata-mata digunakan untuk kegiatan ritual saja. Dalam perjalanan sejarah Islam yang panjang dapat dikatakan bahwa masjid juga mempunyai fungsi dan peran yang tidak kecil dalam proses pembangunan peradaban Islam.

Artefak-artefak peradaban Islam masa lalu selalu tidak dapat dipisahkan dari bangunan masjid. Bahkan artefak yang menonjol jika berbicara mengenai peradaban Islam dari suatu lokalitas dapat dipastikan bahwa masjid akan menjadi sebuah ciri yang tidak dapat ditinggalkan. Oleh karena itu dalam membangun kembali peradaban Islam, yang mampu menebarkan rahmat kepada alam sekitarnya, pada dasarnya, yaitu sebagai pusat kegiatan kaum muslimin.

Perkembangan arus modernisasi yang semakin membumbung merupakan bentuk bagaimana setiap individu untuk mampu bertahan dan menggiring arus tersebut dalam dampak yang positif. Sifat nalar manusia yang semakin modern menuntut perkembangan peribadatan dan rasa urgennya atau pentingnya agama menjadi titik balik pada kehusyu'an serta intimnya hubungan manusia dengan Tuhan nya (Sang Khaliq). Karena dengan landasan secara mengkristal inilah yang lantas menjadikan sifat alamiah manusia membutuhkan ketenangan Tuhan menjadi sebuah nilai yang besar. Kemudian berbicara dengan pelampiasan bagi setiap hamba ialah melakukan serangkaian ritual atau rutinitas ibadah. Dan urgensitas inilah yang terkadang jarang dimiliki serta banyak dilakukan oleh masing-masing individu. Maka dengan begitu, masjid atau sarana ibadah umat islam baitullah merupakan rujukan yang sentral dalam menemukan ketenangan ibadah manusia atau umat Islam.

\section{PEMBAHASAN}

\section{a. Fungsi Masjid}

Perjalanan dan perkembangan peradaban manusia kini sudah semakin hari semakin kompleks. Terkadang kita menemukan berbagai institusi-institusi baru telah lahir dan diperkenalkan bersamaan dengan fungsinya ditengah kehidupan masyarakat dan khususnya umat Islam. Misalkan saja institusi sekolah sebagai pusat pembelajaran dan belajar, yang pada zaman Rasullullah dan para sahabat belum dikenal.

Perkembangan polarisasi yang demikian menuntut untuk dikajinya kembali mengenai posisi terpadu dari sarana ibadah seperti masjid di tengah-tengah kehidupan. Karena sejak zaman Rosululloh Saw hingga masa sahabat, bahkan hingga zaman kerajaan-kerajaan islam dunia, salah satu fungsi masjid selain sebagai tempat memperdalam keimanan manusia muslim juga sebagai sarana ibadah di dalam pendalaman dan pemahaman keilmuan agama Islam. Kemudian atas dasar inilah yang kemudian menempatkan masjid bukan hanya semata-mata sebagai tempat kegiatan ritual ibadah. Karena hal ini dianggap sebagai sebuah sikap yang

${ }^{1}$ Asep, Usman Ismail dan Cecep Castrawijaya, Manajemen Masjid, (Bandung: Angkasa, 2010), h. 2 
disamping mengingkari sejarah juga mengabaikan berbagai potensi yang lahir dari baitullah ini.

Salah satu potensi yang dimiliki oleh masjid adalah selain dari rutinitas kegiatan sholat lima waktu yang wajib bagi umat Islam, juga terselenggaranya kegiatan periodik ibadah shalat jum'at yang di dimana sejumlah besar kaum muslimin berkumpul mendengarkan khotbah jum'at dan dilanjutkan dengan shalat wajib dua rakaat. Berkumpulnya sejumlah besar kaum muslimin secara periodik merupakan salah satu potensi yang dapat digunakan untuk menggalang hal-hal yang positif bagi perkembangan dan pertumbuhan masyarakat. Tersedianya ruang dan jumlah fasilitas juga merupakan suatu potensi, khususnya di kota-kota besar dimana ruang (space) semakin mahal harganya.

Dilihat dari segi harfiah, masjid memanglah tempat sembahyang. Perkataan Masjid berasal dari bahasa Arab. Kata pokoknya sujudan, fi'il madinya sajada (ia sudah sujud). Fi'il sajada diberi awalan ma, sehingga terjadilah isim makan. Isim makan ini menyebabkan perubahan bentuk sajada menjadi masjidu, masjidu masjid. ${ }^{2}$

Masjid adalah tempat bersujudnya makhluk kepada Allah swt pencipta alam semesta. Penampilan dan isi masjid mencerminkan derajat hubungan manusia dengan Allah, dan antara manusia dengan manusia. Pada umumnya wajah masjid akan bergantung kepada taraf iman manusia, makin tinggi iman maka makin makmurlah masjid itu ataupun sebaliknya. Secara sederhana dapat dimaknai bahwa masjid merupakan alat pemantau yang memberikan petunjuk apakah umat manusia itu dalam keadaan beriman tebal atau tipis. Sebagaimana firman Allah yang berbunyi;

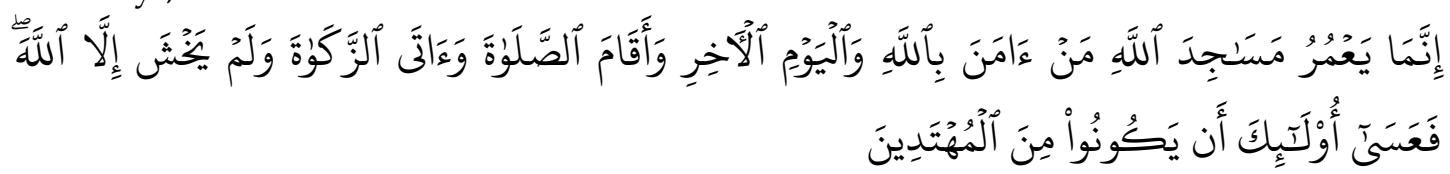

Artinya: "Hanyalah yang memakmurkan mesjid-mesjid Allah ialah orang-orang yang beriman kepada Allah dan hari kemudian, serta tetap mendirikan shalat, menunaikan zakat dan tidak takut (kepada siapapun) selain kepada Allah, maka merekalah orang-orang yang diharapkan termasuk golongan orang-orang yang mendapat petunjuk. (Q.S At-taubah ayat 18) 3

Bersamaan dengan proses pembangunan masjid yang semangkin marak terjadi dimasyarakat dan bahkan sudah hampir sama dengan melakukan perlombaan, namun mirisnya eksistensi masjid tidak memberikan nilai pengembangan apa-apa, bangunan fisik yang rata-rata menjadi prioritas utama nilai Masjid untuk dinilai bagus dan megah. Terlepas dari sifat dan fungsinya masjid dalam menciptakan kenyamanan dalam beribadah dan menghadap Sang Khaliq, terdapat posisi yang sangat fundamental ialah pembangunan dan pengembangan masyarakat islam. Inilah yang sekiranya dianggap untuk perlu mendapatkan perhatian dan berkonsentrasai dalam pengembangan dan melahirkan kesadaran untuk umat islam bersama-sama dalam membangun umat dalam kajian social religion.

Sudah seharusnya dalam masyarakat yang selalu berpacu dengan kemajuan zaman, dinamika Masjid-Masjid juga seyogyanya menyesuaikan diri dengan kemajuan ilmu dan teknologi. Artinya, Masjid tidak hanya berfungsi sebagai tempat ibadah shalat, tetapi juga sebagai wadah beraneka kegiatan jama'ah atau umat Islam.

2Sidi Gazalba, Mesjid Pusat Ibadat dan Kebudayaan Islam, (Jakarta: Pustaka Antara 1983), h. 118

${ }^{3}$ Departemen Agama RI, Al Qur'an dan Terjemahnya, (Bandung: Dipenegoro, 2004), h. 189 
Sebab, Masjid merupakan integritas dan identitas umat Islam yang yang terintegrasi sebagai bentuk mencerminkan tata nilai keislamannya. Dengan demikian, peranan dan fungsi Masjid tidak hanya menitikberatkan pada pola aktivitas yang bersifat akhirat, tetapi memperpadukan antara aktivitas ukhrawi dan aktivitas duniawit. Maka atas berbagai dasar inilah kita dapat menciptakan suasana dan kondisi bahwasanya masjid menjadi sebagai sumber berbagai kegiatan ajaran Islam, bukan hanya dalam upaya peningkatan pengamalan ibadan dan akan tetapi menjadi berbagai proses kegiatan yang akan membawa kita pada pengembangan, pemberdayaan dan kemajuan umat.

Apabila kita hendak melihat pada masa sekarang, Masjid dapat dimaksimalkan sebagai pusat pembinaan umat dengan memperbanyak sisi aktivitas. Aktivitas Masjid semestinya tidak hanya menyentuh atau melibatkan sekelompok orang atau golongan dan aktivitasnyapun tidak hanya berupa ibadah tertentu yang bersifat ritual. Aktivitas Masjid harusnya menyentuh dan melibatkan sekelompok jama'ah mulai dari anakanak, remaja, pemuda, orang dewasa sampai orangtua yang sudah lanjut sekalipun. Di samping itu, pelibatan jama'ah juga tidak memandang perbedaan dari segi pria dan wanita, kaya dan miskin atau yang berpendidikan tinggi dan rendah. Oleh karena itu, Masjid harus memiliki program yang banyak dan bervariasi sesuai dengan kebutuhan dan kemampuan melaksanakannya, menyiapkan fasilitas fisik Masjid yang memadai, manajemen kepengurusan yang solid dan administrasi yang baik ${ }^{5}$.

\section{Optimalisasi Fungsi Masjid}

Sejak empat belas abad silam, Rasulullah Saw telah menunjukkan tuntunannya dalam hal pemakmuran masjid, begitu pula di zaman keemasan Islam (sejak abad ke 6-13 $\mathrm{M}$ atau selama 7 abad), umat Islam berhasil menjadikan masjid sebagai markas pelaksanaan hubungan antara manusia dengan Allah Swt (ibadah) dan hubungan manusia dengan manusia (muamalah). 6 Dengan demikian dapat disimpulkan bahwa secara ideal, Masjid memiliki peran dan fungsi sebagai Pusat Ibadah serta Pembinaan umat dalam segala bidang.

Optimalisasi fungsi dan peran masjid sebagai pusat pembinaan umat, tidak mungkin dapat dikelola oleh satu atau sekelompok kecil orang, tetapi harus melibatkan semua komponen yang berada disekitarnya. Caranya dapat menyentuh hati masyarakat sehingga mereka merasa memilikinya. Keterlibatan mereka dalam melaksanakan fungsi masjid memerlukan manajemen pengelolaan yang baik sehingga semua komponen masyarakat merasa terlibat dan ada rasa memiliki terhadap masjid tersebut. Artinya, bagaimana kita mengelola masjid dengan benar dan profesional sehingga dapat menciptakan suatu masyarakat yang sesuai dengan keinginan Islam, yaitu masyarakat yang baik sejahtera, rukun, damai, dengan ridho, berkah dan rahmat Allah Swt, sehingga masyarakatnya memberikan rahmat pada alam dan masyarakat sekitarnya.7 Dari situlah akan timbul tanggung jawab untuk sama-sama meramaikan dan merawatnya dengan baik. Ada beberapa kegiatan yang dapat dilakukan sebagai bentuk pengoptimalisasian fungsi dan peran masjid, yaitu:

${ }^{4}$ Muhammad E. Ayub, Manajemen Masjid, (Gema Insani Press: Jakarta, 1996), h. 1

${ }^{5}$ Fini Fitriani Siregar, Fungsi Manajemen Masjid, dalam: http: //finifitrianisiregar. blogspot.com/ 2010/12/ fungsimanajemen-masjid.html// diakses pada 05 Desember 2018

6 M. Hajar Dewantoro, "Profil Penerapan Manajemen Masjid di Kecamatan Ngemplak Sleman," dalam: www.google.com/pdf-file// diakses pada 12 Desember 2018

7 Sofyan Safri Harahap, Manajemen Masjid, Suatu Pendekatan Teoritis dan Organisatoris, (Yogyakarta: PT Dhana Bakti Wakaf, 1993), h. 28. 
Pertama, Sebagai Tempat Ibadah. Sesuai dengan namanya masjid adalah tempat sujud, maka fungsi utamanya sebagai tempat ibadah shalat. Sebagaimana kita ketahui bahwa makna ibadah di dalam islam adalah luas menyangkut segala aktifitas segala kehidupan yang ditujukan untuk memperoleh ridha Allah swt. Maka fungsi masjid di samping sebagai tempat shalat juga sebagai tempat beribadah secara luas sesuai dengan ajaran Islam.

Kedua, Sebagai Tempat Menuntut Ilmu. ${ }^{8}$ Masjid berfungsi sebagai tempat untuk belajar mengajar, khususnya ilmu agama yang merupakan fardhu 'ain bagi umat islam. Di samping juga untuk belajar mengajar ilmu-ilmu yang lain, baik ilmu alam, sosial, humaniora, keterampian, stategi berperang dan lain sebagainya yang dapat diajarkan di masjid. ${ }^{9}$

Ketiga, Sebagai Tempat Pembinaan Jama'ah. Dengan adanya umat islam di sekitarnya, masjid berperan dalam mengkordinir guna menyatukan potensi dan kepemimpinan umat. Selanjutnya umat yang terkordini secara rapi dala organisasi ta'mir masjid dibina keimanan, ketaqwaan, ukhuwah imaniyah dan dakwah islamiyahnya. Sehingga masjid menjadi basis umat yang kokoh. ${ }^{10}$

Keempat, Sebagai Pusat Dakwah dan Kebudayaan Islam. Masjid merupakan jantung kehidupan umat islam yang selalu berdenyut untuk menyebarluaskan dakwah islamiyah dan budaya islami. Di masjid pula direncanakan, diorganisasikan, dikaji, dilaksanakan dan dikembangkan dakwah dan kebudayaan islam yang menyahuti kebutuhan masyarakat. Karena itu, masjid berperan sebagai sentra aktivitas dakwah dan kebudayaan.

Kelima, Sebagai Pusat Kaderisasi Umat. Sebagai tempat pembinaan jama'ah dan kepemimpinan umat, masjid memerlukan aktivis yang berjuang menegakkan islam secara istiqamah. Patah tumbuh hilang berganti. Karena itu, pembinaan kader perlu dipersiapkan dan dipusatkan di masjid sejak mereka dari kecil sampai dewasa. Di antaranya dengan Taman Pendidikan al-Qur'an (TPQ), remaja masjid maupun takmir masjid beserta kegiatannya.

Keenam, Sebagai Pusat Pengembangan Ekonomi Umat. Dari waktu-kewaktu peranan masjid semakin luas dan meningkat. selain sebagai tempat ibadah, masjid juga berfungsi sebagai tempat kegiatan sosial umat, seperti dalam upaya membantu dan meningkatkan perekonomian umat umat melalui zakat, infaq dan shadaqah dan lain-lain.

\section{Masjid Sebagai Model Pengembangan Masyarakat Islam}

Pengembangan masyarakat adalah kemampuan suatu negara atau suatu bangsa untuk terus berkembang baik secara kualitatif atau kuantitatif yang mencakup seluruh kehidupan bernegara dan bermasyarakat dan karena tidak berkembang hanya dalam arti peningkatan taraf hidup saja akan tetatpi dala segi kehidupan lainnya, manusia bukan hanya makhluk ekonomi, akan tetapi juga makhluk sosial dan politik. Oleh karena itu perlu diadakan perubahan struktur ekonomi dan non ekonomi. Sedangkan menurut A. Supardi bahwa pengembangan masyarakat itu adalah suatu proses dimana anggota masyarakat pertama-tama mendiskusikan dan menentukan keinginan mereka kemudian merencanakannya dan menerjakan bersama-sama untuk memenuhi keinginan mereka tersebut. Pengembangan masyarakat juga merupakan

${ }^{8}$ Ahmad Yani, Panduan Memakmurkan Masjid, (Al-qalam: Jakarta, 2009), h. 56

${ }^{9}$ Muhammad 'Ajaj al-Khatib, Ushulu al-Hadits, 'Ulumuhu wa Mushthalahuhu. (Lebanon, Beirut 2006), h. 39

${ }^{10}$ Supriyanto Abdullah, Peran dan Fungsi Masjid, (Cahaya Hikmah: Yogyakarta, 1997), h. 10 
suatu gerakan untuk menciptakan suatu kehidupan yang lebih baik bagi seluruh masyarakat dengan berpartisipasi aktif da inisiatif masyarakat itu sendiri. ${ }^{11}$

Secara umum pengembangan masyarakat (community development) adalah kegiatan pengembangan masyarakat yang dilakukan secara sistematis, terencana, dan diarahkan untuk memperbesar akses masyarakat guna mencapai kondisi sosial, ekonomi, dan kualaitas kehidupan yang lebih baik apabila dibandingkan dengan kegiatan pembangunan sebelumnya. ${ }^{12}$

Seperti yang telah dijelaskan pada bagian sebelumnya bahwa secara umum masjid yang akar katanya mengandung arti tunduk dan patuh, memiliki pemaknaan yang luas. Masjid selain berfungsi memenuhi keperluaan ibadah islam, fungsi dan perannya ditentukan oleh lingkungan, tempat dan jamaah dimana masjid didirikan. tentunya terdapat juga masalah social yang ada dimasyarakat seperti kemiskinan, masalah keluarga, kenakalan remaja, kesehatan, ekonomi dan yang lainnya, maka kita bisa menjadikan masjid sebagai media untuk menyelesaikannya. Hal ini memang bisa aja dilakukan karena memang secara prinsip majsid merupakan tempat membina umat, yang meliputi penyambung ukhuwah, wadah membicarakan masalah umat, serta pembinaan dan pengembangan masyarakat ${ }^{13}$.

Adapun bentuk penyelesaian masalah oleh masjid ini bermacam-macam, mulai dari pengajian, kajian ilmu, zakat, TPA, pembinaan remaja, pembinaan orang tua, beasiswa, konseing, dan lain sebagainya. Tentu saja yang paling banyak perannya dalam ini adalah para pengurus masjid yang berkecimpung di dalamnya. Jadi dalam hal ini masjid tidak hanya mempunyai fungsi dari segi bangunannya saja, tetapi dari sumber daya yang berada dalam masjid juga bisa dijadikan solusi untuk menyelesaikan masalah social di masyarakat. Dengan demikian maka peranan dan fungsi masjid tidak hanya menitikberatkan pada pola aktivitas yang bersifat akhirat, tetapi memadukan antara aktivitas ukhrawi dan aktivitas duniawi.

\section{Masjid dan Peradaban Islam}

Jika dikaji secara mendalam, dinamika peradaban Islam berjalan selaras dengan perluasan dan pengayaan fungsi masjid bagi komunitas Muslim. Dalam perjalanan sejarah Islam, masjid bukan sekadar tempat untuk menunaikan ibadah shalat (terutama shalat berjamaah), namun juga berperan lebih fenomenal dan krusial dalam menunjang kehidupan masyarakat. Islam mengajarkan pendirian masjid harus memberikan manfaat luas, terdalam dan lengkap mengingat seluruh permukaan bumi adalah masjid. sejarah mencatat bahwa pada permulaan perkembangan islam ke berbagai negeri, bila umat menetap di suatu daerah baru, maka salah satu sarana untuk kepentingan mereka adalah masjid. ${ }^{14}$

Kata masjid berakar dari bahasa Arab (tergolong dalam rumpun bahasa AfroAsia), yakni bahasa Semitik yang menjadi bahasa asli sebagian besar kitab Daniel dan Ezra dan merupakan bahasa utama Talmud -bahasa ibu dari Nabi Isa AS. Kata masgid ditemukan dalam sebuah inskripsi dari abad ke-5 sebelum Masehi yang berarti tiang suci atau tempat sembahan. Dalam bahasa Arab, masjid berarti tempat

${ }^{11}$ A. Supardi, dakwah Islam dengan Pengembangan Masyarakat Desa, (Bandung: Madar Maju, 1987), h. 24-27

12 Arif Budimanta dan Bambang Rudito, Metode dan Teknik Pengelolaan Community Development, cet. Ke II (Jakarta: CSD, 2008), hal. 33.

${ }^{13}$ Aisyah Nur Handryant, Masjid Sebagai Pusat Pengembangan Masyarakat,(Malang; Uin Maliki, 2010), h. 66

${ }^{14}$ Tim Penertbit, Ensiklopedi Islam Jilid 3, (Jakarta: Ikhtiar Baru Van Hoeve, 1994), h. 170 
sujud atau tempat ibadah. ${ }^{15}$ Sujud berasal dari kata kerja bahasa Arab, yakni sajada adalah sujud atau tunduk yang berarti meletakkan kening di atas permukaan bumi untuk beribadah kepada Allah SWT. Karena bumi ini ciptaan Al-Qahhaar (Yang Memiliki Mutlak Sifat Memaksa) sehingga seluruh permukaannya juga milik AlWahhaab (Yang Memiliki Mutlak Sifat Pemberi Karunia) maka secara harafiah ibadah shalat dapat dilakukan di mana saja.

Peradaban Islam selalu mencontohkan bahwa pendirian dan pemanfaatan masjid harus lebih dikembangkan dan lebih diperluas bagi kehidupan kaum Muslim. Sebab jika hanya dipakai sebagai tempat shalat, umat Islam dapat melakukannya di luar masjid, yakni di seluruh tempat di atas permukaan bumi. Hal ini seperti yang dikutip dari Jabir bin 'Abdullah, bahwasanya Nabi Saw pernah bersabda: "Aku dikarunia lima perkara yang belum pernah diberikan kepada seorangpun sebelum aku;

1) Aku ditolong dengan kegentaran (musuh meghadapi aku) jarak sejauh sebulan perjalanan

2) Dan dijadikan bumi ini bagi ku sebagai masjid dan bahkan pensuci, lalu dimana saja seseorang dari umat ku mendapatkan waktu shalat, ia boleh melakukan shalat disitu.

3) Dan dihalalkan bagi ku ramparan perang, padahal tidak dihalalkan bagi seseorang sebelum aku.

4) Juga aku diizinkan memberi syafa' ah (pada hari kiamat).

5) Dan apapun Nabi-Nabi (diutus) hanya untuk kaumnya semata-mata, sedangkan aku untuk manusia seluruhnya. (HR Bukhari dan Muslim)16.

Muhammad Saw adalah manusia yang pertama kali meneladani dalam memperluas dan memperkaya fungsi masjid. Ketika hijrah dan mendirikan Negara Madinah, Rasulullah menjadikan Masjid Madinah (dikenal sebagai Masjid Nabawi) sebagai pusat kegiatan pemerintahan. Sebagai jantung kota Madinah saat itu, Masjid Nabawi digunakan untuk kegiatan politik, perencanaan kota, menentukan strategi militer dan untuk mengadakan perjanjian kerja sama bahkan di area sekitarnya digunakan sebagai tempat tinggal sementara oleh orang-orang fakir miskin. Setelah Nabi wafat, Masjid Nabawi tetap dijadikan sebagai pusat kegiatan para khalifah, sebagaimana yang dilakukan oleh al-Khulafa al-Rãsyidữn sepanjang tahun 632-660.

Fungsi Masjid Nabawi sebagai pusat kegiatan para khalifah terus berlanjut. Bahkan pada saat itu, fungsi Masjid Nabi semakin diperluas sebagai pusat pertemuan para sahabat dan pemimpin Muslim lainnya. Karena menjadi pusat dakwah bagi kaum mualaf dalam rangka menerima pelajaran dasar tentang Islam- akibatnya fungsi masjid sebagai pusat pendidikan Islam menjadi semakin mengkristal. Dari sanalah penguatan fungsi masjid sebagai sentra pelayanan pendidikan dan penyebaran keilmuan yang bernuansa Islam telah mulai tumbuh. Dan mulai dari fase itu, fungsi masjid sebagai sentral pengembangan peradaban Islam mulai berkembang. Masjid kemudian dibangun di luar Semenanjung Arab, seiring dengan kaum Muslim yang bermukim di luar Jazirah Arab.

Mesir menjadi daerah pertama yang dikuasai oleh kaum Muslim Arab pada tahun 640. Sejak saat itu, Ibukota Mesir, Kairo dipenuhi dengan masjid, sehingga dijuluki sebagai kota seribu menara. Dan beberapa masjid di Kairo juga mengikuti keteladanan Masjid Nabi karena berfungsi sebagai sekolah Islam atau madrasah

15 Abdul Chaer, Kamus Populer Praktis, (Jakarta: PT Rieneka Cipta, 2010), Cet. Ke 1a, h.14

${ }^{16}$ https://alhadistonline.wordpress.com/, diakses pada tanggal 15 Desember 2018, Pukul 21.25 WIB 
bahkan rumah sakit. Pembangunan masjid yang dicontohkan Nabi Muhammad Shallallahu 'alaihi wasallam, yang kemudian dilanjutkan oleh para sahabat, yang juga sebagai khalifah pada waktu itu, dipastikan selalu dan terus menjadi dasar rujukan dalam membangun dan mengembangkan masjid sebagai sebuah pusat pengembangan Islam semenjak abad permulaan Islam hingga akhir zaman ${ }^{17}$.

Penyatuan rancang bangun lanskap masjid yang terbagi ke dalam beberapa fungsi kegiatan tersebut sesungguhnya bersumber dari tawhidic paradigm. Paradigma Tauhid mengartikan adanya kesatuan kehidupan yang berpusat pada masjid. Masjid sebagai simbol keimanan dan ke-Islaman menjadi pusat kegiatan ibadah yang selanjutnya menyebar ke aspek-aspek kegiatan berikutnya yang juga teramat penting dalam mendukung kehidupan masyarakat Muslim.

Paradigma Tauhid memosisikan agama sebagai inti kehidupan dan tidak ada pemisahan antara hal-hal yang bersifat sakral maupun profan. Antara kegiatan yang memberi makna bagi kepentingan duniawi maupun akhirat dapat dilakukan secara terintegrasi dan terkait dengan dimensi keagamaan dan bahkan dapat dikemas sebagai pancaran (eksistensi) keimanan dan ibadah. Belajar dari sejarah Islam, seharusnya eksistensi masjid pada masa kini harus lebih mampu memberi makna terdalam, terluas dan terlengkap bagi kehidupan masyarakat Muslim. Karena itu, pengembangan dan pengayaan ulang atau revitalisasi fungsi masjid sebagai pusat berbagai kegiatan sosial-keagamaan, pendidikan, politik, kesehatan dan sebagainya kini menjadi lebih diperlukan. Tujuannya untuk menciptakan manfaat dan dampak masjid yang maksimal serta berkesinambungan dalam mengembangkan peradaban dunia Islam yang maju, ramah, mandiri, damai dan modern. ${ }^{18}$

\section{Kesimpulan}

Selain sebagai sarana atau tempat suci yang rutin 24 jam digunakan oleh umat Muslim (Islam), masjid secara mengkristal ada dibenak semua umat Islam bahwasanya masjid merupakan tempat bagi seluruh hamba-hamba Tuhan meminta dan memohon pada yang pemilik Hidup. Kemudian perkembangan dan kemajuan peradaban, menjadikan perjalanan masjid menjadi berbagai kesatuan utuh sebagai bentuk interpretasi manusia meng-Agungkan Allah Swt.

Tempat sujud, berdoa, berdzikir atas nama kebesaran Sang Khaliq merupakan konsep tersendiri bagi setiap musllim dalam menjalankan amalannya. Kemudian perkembangan dan kemajuan zaman yang semakin kompleks dan menjadikan manusia terkadang lalai dalam menjalankan aktifitas, baitullah inilah mejadi saksi atas persaksian doa-doanya setiap hamba.

Sebuah nilai pengelolaan atau manajemen Masjid seiring berjalannya waktu sejak dibangunya masjid pertama oleh Rosululloh Saw di Madinah dan hingga sampai massa sekarang. Telah banyak memberikan corak dan kejelasan akan perjalanan sejaran di dalam mengembangkan kemampuan masyarakat Islam dalam ke Tauhidan dan ke Akidahan pada Allah dan Rosul. Kemudian hal inilah yang menjadikan perjalanan dan harmonisasi antara iman manusia dan sarana hati dalam menuju Rabbnya.

Pemberdayaan dan pengembangan masyarakat islam yang dibangun melalui fungsinya (masjid), menjadi kejelasan betapa Allah menurunkan Rahmat-Nya atas

\footnotetext{
17 Taufik Abdullah et. al., Sejarah Umat Islam di Indonesia, (Jakarta: Majelis Ulama Indonesia, 1991), h. 36-43

18 Amrullah Ahmad, Perspektif Dakwah Islam dalam Masyarakat Industri dalam PJP II: Sebuah Ikhtiar mencapai Dakwah Tahun 2000, Makalah, h. 6
} 
seluruh alam dengan memberikan tanda-tanda kebesaran-Nya. Pemberdayaan masyarakat yang terjadi dalam kehidupan umat islam pada kurun massa, memberikan sebuah ilustrasi kehidupan yang indah. Masjid, selain dipergunakan oleh umat islam sebgaai sarana menghadapkan diri pada sang Khaliq, pada masa Nabi dipergunakan sebagai sarana bersilaturahmi dan berkumpulnya umat muslim dalam membicarakan urusan dunia (politik, niaga, sosial kemasyarakatan dan lain-lainya).

Selain fungsi keharmonisasian, antara keduanya juga terjalin sebuah komunikasi sepiritual yang emosional. Implementasi nilai-nilai keislaman yang dibalut dengan keimanan dan ketaqwaan pada Allah, menjadikan nilai manusia luhur atas iman islamnya. Kemudian masjid menjadi jembatan akan terhubungnya sarana yang bernama hablumminallah wa hablumminannas.

Berfungsi sebagai tempat beribadah yang husyu', pembinaan ummat, sarana pembinaan jama \ah, tempat pendidikan atau pengembangan keilmuan islam, kegiatan sosial, pusat pengembangan ekonomi keumatan dan berdakwah serta kebudayaan Islam. Fungsi-fungsi sentral inilah yang seyogyanya menjadikan sebuah perhatian dan kajianhusus dalam pengembangan dan pengelolaan dalam pemberdayaan umat muslim agar kuat secara lahir dan batin, kuat iman islam taqwanya.

\section{Refrensi}

Abdul Chaer, Kamus Populer Praktis, (Jakarta: PT Rieneka Cipta, 2010), Cet. Ke 1a Ahmad Yani, Panduan Memakmurkan Masjid, (Al-Qalam: Jakarta, 2009)

Aisyah Nur Handryant, Masjid Sebagai Pusat Pengembangan Masyarakat,(Malang; UIN Maliki, 2010)

Amrullah Ahmad, Perspektif Dakwah Islam dalam Masyarakat Industri dalam (PJP II: Sebuah Ikhtiar mencapai Dakwah Tahun 2000)

Arif Budimanta dan Bambang Rudito, Metode dan Teknik Pengelolaan Community Development, cet. Ke II (Jakarta: CSD, 2008)

Asep, Usman Ismail dan Cecep Castrawijaya, Manajemen Masjid, (Bandung: Angkasa, 2010)

A. Supardi, dakwah Islam dengan Pengembangan Masyarakat Desa, (Bandung: Madar Maju, 1987)

Sidi Gazalba, Mesjid Pusat Ibadat dan Kebudayaan Islam, (Jakarta: Pustaka Antara, 1983)

Departemen Agama RI, Al Qur'an dan Terjemahnya, (Bandung: Dipenegoro, 2004)

Muhammad E. Ayub, Manajemen Masjid, (Gema Insani Press: Jakarta, 1996)

Sofyan Safri Harahap, Manajemen Masjid, Suatu Pendekatan Teoritis dan Organisatoris, (Yogyakarta: PT Dhana Bakti Wakaf, 1993)

Tim Penertbit, Ensiklopedi Islam Jilid 3, (Jakarta: Ikhtiar Baru Van Hoeve, 1994)

Muhammad 'Ajaj al-Khatib, Ushulu al-Hadits, 'Ulumuhu wa Mushthalahuhu. (Lebanon: Beirut, 2006)

Taufik Abdullah et. al., Sejarah Umat Islam di Indonesia, (Jakarta: Majelis Ulama Indonesia, 1991)

Supriyanto Abdullah, Peran dan Fungsi Masjid, (Cahaya Hikmah: Yogyakarta, 1997)

\section{Refrensi Internet}

Fini Fitriani Siregar, Fungsi Manajemen Masjid, dalam: http: //finifitrianisiregar. blogspot.com/2010/12/ fungsi-manajemen-masjid.html// diakses pada $05 \mathrm{Juli}$ 2020 
M. Hajar Dewantoro, "Profil Penerapan Manajemen Masjid di Kecamatan Ngemplak Sleman," dalam: www.google.com/pdf-file// diakses pada 12 Juli 2020

https://alhadistonline.wordpress.com/, diakses pada tanggal 15 Juli 2020, Pukul 21.25 WIB 